\title{
Gibberellin- and Cytokinin-induced Growth and Flowering Responses in Rudbeckia hirta L.
}

\author{
Richard L. Harkess ${ }^{1}$ and Robert E. Lyons ${ }^{2}$ \\ Department of Horticulture, Virginia Polytechnic Institute and State University, \\ Blacksburg, VA 24061-0327
}

Additional index words. Asteraceae, benzyladenine, $\mathrm{GA}_{4+7}$

\begin{abstract}
BA and $\mathbf{G A}_{4+7}$, were applied to vegetative, mature Rudbeckia hirta plants at the beginning of long days (LD). There were no synergistic effects, but BA inconsistently affected branching and had no effect on flowering. Floral initiation of the terminal inflorescence was promoted by $\mathbf{G A}_{477}$, although axillary inflorescences were not. Increasing $\mathbf{G A}_{4+7}$ levels decreased the time to terminal inflorescence anthesis. However, the interval between the terminal and second axillary inflorescence anthesis was increased. The net result was no significant effect on the time to second axillary inflorescence anthesis. Gibberellins may enhance the LD effect on the apical meristem of Rudbeckia, but axillary meristems, which initiate later, remained unaffected. Chemical names used: benzyladenine (BA), gibberellin ${ }_{4+7},\left(\mathbf{G A}_{4+7}\right)$.
\end{abstract}

Cytokinins applied to the apex of plants during noninductive photoperiods can evoke a variety of apical changes, including cell divisions that normally occur early in floral initiation (Bernier and Kinet, 1986). Ogawa and King (1979) reported that cytokinins enhance translocation of the floral stimulus and assimilates from induced leaves, thereby promoting flowering. When applied during floral initiation, BA increased the floret count and capitulum size in the short-long-day plant Leucospermum cordifolium (Salisb. ex. Knight) x L. lineare R. Br. (Napier et al., 1986) and the flower count of the short-day (SD) plant Schlumbergera truncata (Haw.) Moran (Ho et al., 1985; Runger and Poole, 1985). When cytokinins were applied to Schlumbergera under noninductive photoperiods, phylloclade (branch) count was increased.

Applications of gibberellins (GA) to long-day (LD) rosette plants under noninductive photoperiods often result in bolting and, occasionally, flowering (Bernier and Kinet, 1986). GA promoted Gaillardia $\times$ grandiflora van Houtte flowering by substituting for and enhancing LD stimuli (Evans and Lyons, 1988). When applied under SD, GA stimulated meristematic cell proliferation in the subapical and central zone, which led to stem elongation and floral initiation in Rudbeckia hirta (syn: $R$. bicolor) (Bernier and Kinet, 1986). The sensitivity of $R$. hirta to GA under SD depended on plant age (Kochankov et al., 1987). The pro-

Received for publication 24 Mar. 1993. Accepted for publication 18 Oct. 1993. The cost of publishing this paper was defrayed in part by the payment of page charges. Under postal regulations, this paper therefore must be hereby marked advertisement solely to indicate this fact.

Graduate Assistant.

${ }^{2}$ Associate Professor. motion of floral initiation using GA, however, is not consistent across genera. Under LD, GA-antagonist growth retardants prevented bolting and flowering in the LD plant Samolus parviflorus Raf., but GA applications overrode these effects. InSilene armeria L., growth retardants suppressed stem elongation but not flowering, indicating that floral initiation and development and GA levels are unrelated in this species (Bernier and Kinet, 1986).

Combining cytokinins and GA has been effective in increasing the number of pistillate ray florets in Helianthus annuus L. (Sladky, 1986). However, when this combination was applied to Schlumbergera under inductive SD, GA caused phylloclade elongation, flower bud initiation, and lateral phylloclade development, while reducing the number of flowers produced by BA alone (Ho et al., 1985).

As reported in other species, the potential exists in $R$. hirta for increasing either the number of inflorescences or the number of florets in an inflorescence using cytokinins and gibberellins. The present study was conducted to examine the effects of $\mathrm{BA}$ and $\mathrm{GA}_{4+7}$ applied during floral induction on the flowering of $R$. hirta.

\section{Materials and Methods}

Seeds of the obligate LD plant $R$. hirta were sown in Sunshine Mix 1 (Fisons Horticulture, Vancouver, B. C.) and grown under SD conditions provided by covering the plants with black cotton cloth from 1700 to $0800 \mathrm{HR}$. Seedlings were transplanted into the same medium and grown to maturity (14 to 16 expanded leaves) (Orvos and Lyons, 1989) in $1500-\mathrm{cm}^{3}$ containers. The plants were fertilized weekly during irrigation with $400 \mathrm{mg} \mathrm{N} /$ liter from $20 \mathrm{~N}-6.6 \mathrm{P}-17.6 \mathrm{~K}$. At maturity, the plants were moved to LD, which consisted of ambient greenhouse light [623 to 833 $\mu \mathrm{mol} \cdot \mathrm{m}^{-2} \cdot \mathrm{s}^{-1}$ average photosynthetic photon flux density (PPFD) at $1200 \mathrm{HR}$ ] plus a 4-h night interruption from 2200 to $0200 \mathrm{HR}$ using 60 -W incandescent bulbs ( 3 to $4 \mu \mathrm{mol} \cdot \mathrm{m}^{-2} \cdot \mathrm{s}^{-1}$ PPFD). Treatments were applied at the start of LD and consisted of 0,20 , or $50 \mu \mathrm{g}$ a.i. BA (ABG-3062, 2\% aqueous; Abbot Laboratories, North Chicago, Ill.) and 0, 100, or $200 \mu \mathrm{g}$ a.i. $\mathrm{GA}_{4+7}(\mathrm{ABG}-3035,2 \%$ aqueous; Abbot Lab.) in $2 \mathrm{ml}$ aqueous solution pipetted onto the apical meristematic region. Treatments were applied in a randomized complete factorial design with 15 replications.

The number of days to anthesis of the terminal and second axillary inflorescence, number of distillate ray florets, the terminal and second axillary inflorescence disk diameter, days between anthesis of the terminal and second axillary inflorescence, number of branches, number of leaves on the main stem, and plant height were measured at the time of terminal inflorescence anthesis. The disk floret inflorescence diameter was measured at anthesis of the first row of disk florets because florets continue to initiate over an extended period.

\section{Results}

No significant interactions between $\mathrm{GA}_{4+7}$ and BA were found. In addition, there were no significant treatment effects on distillate ray floret count, disk floret inflorescence diameter, plant height, or number of leaves (data not shown). Significant main effects were observed on branch count, days to inflorescence anthesis, and the difference between days to terminal and second axillary inflorescence anthesis.

BA applied at $20 \mu \mathrm{g}$ significantly reduced branch count (17) in $R$. hirta compared to the control and the 50- $\mu$ g treatment (20 and 19, respectively; Student-Newman-Kuels test, $P$ $\leq 0.01$ ). However, the control and $50-\mu \mathrm{g}$ treatments were not significantly different

$\mathrm{GA}_{4+7}$ applied at 100 or $200 \mu \mathrm{g}$ a.i. significantly decreased days to terminal inflorescence anthesis, but had no significant effect on days to second axillary inflorescence anthesis (Table 1). Anthesis of the second axillary inflorescence to flower occurred an average of 5 days after the terminal inflorescence when treated with $200 \mu \mathrm{g} \mathrm{GA}_{4+7}$, while the control plants flowered only 3 days after the terminal inflorescence.

Table 1. Effects of $\mathrm{GA}_{4+7}$ on the number of days to anthesis of the terminal inflorescence (TI) and second axillary inflorescence (SAI) and days between inflorescence anthesis in Rudbeckia hirta.

\begin{tabular}{|c|c|c|c|}
\hline 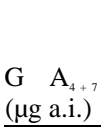 & $\begin{array}{c}\text { Terminal } \\
\text { inflorescence } \\
\text { (days) }\end{array}$ & $\begin{array}{c}\text { Second } \\
\text { axillary } \\
\text { inflorescence } \\
\text { (days) }\end{array}$ & $\begin{array}{c}\text { TI and } \\
\text { SAI } \\
\text { difference } \\
\text { (days) }\end{array}$ \\
\hline 0 & $79 a^{2}$ & $82 \mathrm{a}$ & $3 b$ \\
\hline 100 & $74 \mathrm{~b}$ & $78 \mathrm{a}$ & $4 a b$ \\
\hline 200 & $73 \mathrm{~b}$ & $78 \mathrm{a}$ & $5 \mathrm{a}$ \\
\hline
\end{tabular}

${ }^{2}$ Mean separation within columns by StudentNewman-Keuls test, $P<0.05$. 


\section{Discussion}

Cytokinins enhance translocation of the floral stimulus and assimilates from induced leaves (Ogawa and King, 1979) and increase flower counts (Ho et al., 1985; Napier et al., 1986). Cytokinins applied at times other than specific initiation stages either have no effect, delay flowering, or increase branching (Rünger and Poole, 1985). BA increased phylloclade (branch) counts in Schlumbergera but only when applied before the start of floral initiation (Ho et al., 1985; Rüngerand Poole, 1985). In the present study using $R$. hirta, the effect of BA on branching was inconsistently deleterious when applied at the start of floral induction but before floral initiation.

Gibberellins applied under SD simultaneously stimulate cell proliferation in the subapical tissues and the central zone of the apical meristem (Bernier and Kinet, 1986). In Rudbeckia, stem elongation and flowering are not inextricably linked (Mumeek, 1940). Therefore, enhanced flowering in the terminal inflorescence is likely an early promotion of floral initiation. Yet, as is often observed following exogenously applied growth regulators, the response was temporary, and $\mathrm{GA}_{4+7}$ did not enhance axillary inflorescence initiation in $R$. hirta. In this case, apical floral initiation alone, and not subsequent development, was affected by $\mathrm{GA}_{4+7}$; nor were axillary meristems influenced by the single $\mathrm{GA}_{4+7}$, treatment at the start of LD. Even under SD with GA applied daily for 5 days, Kochankov et al. (1987) observed only apical floral initiation.

These results indicate that BA did not affect flowering in $R$. hirta when applied at the onset of LD. The combination of BA and GA, although effective in increasing pistillate ray floret counts in Helianthus (Sladky, 1986), had no effect in $R$. hirta. $\mathrm{GA}_{4+7}$, applied at the onset of LD, promoted floral initiation in the apical meristem of $R$. hirta without lasting effect, leaving axillary meristem initiation unaffected. Flowering has been promoted in another LD bolting plant, Gaillardia (Evans and Lyons, 1988), where $\mathrm{GA}_{4+7}$ promoted flowering by substituting for and enhancing the $\mathrm{LD}$ stimuli. In Rudbeckia, $\mathrm{GA}_{4+7}$ applied at the onset of LD may enhance the effects of LD in the apical meristem. When applied during floral initiation of the apical meristem, $\mathrm{GA}_{4+7}$, did not enhance floral initiation in the axillary meristems. The net result was no increase in either inflorescence size or count.

\section{Literature Cited}

Bernier, G. and J.M. Kinet. 1986. The control of flower initiation and development, p. 293-302. In: M. Bopp (ed.), Plant growth substances 1985. Springer-Verlag, Heidelberg, Germany.
Evans, M.R, and R.E. Lyons. 1988. Photoperiodic and gibberellin-induced growth and flowering responses of Gaillardia $\times$ grandiflora. HortScience 23:584-586.

Ho, Y., K.C. Sanderson, and J.C. Williams. 1985. Effect of chemicals and photoperiod on the growth and flowering of Thanksgiving cactus. J. Amer. Soc.. Hort. Sci. 110:658-662.

Kochankov, V. G., E.L. Milyaeva, E.A. Zhivukhina, and M.K. Chailakhyan. 1987. Age-dependent response of Rudbeckia bicolor plants to gibberellin $\mathrm{A}_{3}$, p. 463-469. In: D. Lilov (ed,). Plant growth regulators. Proc. IV Intl. Symp. Plant Growth Regulat. 2nd part. Inst. Plant Physiol., Bulgarian Academy of Sciences, Sofia.

Mumeek, A.E. 1940. Length of day and temperature effects in Rudbeckia. Bet. Gaz. 102:269-279.

Napier, D. R., G. Jacobs, J. van Staden, and C. Forsyth. 1986. Cytokinins and flower development in Leucospermum. J. Amer. Soc, Hort. Sci. 111:776-780

Ogawa, Y. and R.W. King, 1979. Indirect action of benzyladenine and other chemicals on flowering of Pharbitis nil Chois. Plant Physiol. 63:643649.

Orvos, A.R. and R.E. Lyons, 1989. Photoperiodic inhibition of stem elongation and flowering in Rudbeckia hirta 'Marmalade'. J. Amer. Soc. Hort. Sci. 114:219-222,

Riinger, W. and R.T. Poole, 1985. Schlumbergera, p. 277-282. In: A.H. Halevy (ed.). CRC handbook of flowering. CRC Press, Boca Raton, Fla

Sladky, Z. 1986. The role of growth regulators in the differentiation of flowers and inflorescences. Biol. Plant. 28:31-37. 